\title{
Hybridization and the phylogenetic relationship between polecats and domestic ferrets in Britain
}

\author{
A. Davison ${ }^{\mathrm{a}, \mathrm{b}, *}$, J.D.S. Birks ${ }^{\mathrm{b}}$, H.I. Griffiths ${ }^{\mathrm{c}}$, A.C. Kitchener ${ }^{\mathrm{d}}$, D. Biggins ${ }^{\mathrm{e}}$, \\ R.K. Butlin ${ }^{\mathrm{a}}$ \\ ${ }^{a}$ Department of Biology, University of Leeds, Leeds LS2 9JT, UK \\ ${ }^{\mathrm{b}}$ The Vincent Wildlife Trust, 10 Lovat Lane, London EC3R 8DT, UK \\ ${ }^{\mathrm{c}}$ Research Institute for Environmental Science and Management, University of Hull, Hull HU6 $7 R X, U K$ \\ ${ }^{\mathrm{d}}$ National Museums of Scotland, Chambers St., Edinburgh EHI 1JF, UK \\ ${ }^{\mathrm{e}}$ National Biological Service, 4512 McMurray Ave., Fort Collins, Colorado 80525, USA
}

Received 15 November 1997; received in revised form 6 June 1998; accepted 8 June 1998

\begin{abstract}
Ferrets (Mustela furo) were domesticated from polecats (M. putorius, M. eversmannii) over 2000 years ago. Following their introduction to Britain, they escaped and hybridized with native European polecats $(M$. putorius). Native polecats declined to the point of near extinction prior to World War I, but have recently begun to expand from a Welsh refugium. Concern has arisen as to the extent of polecat/ferret introgression, and in particular, whether the expanding population is of mainly hybrid origin. Therefore, mitochondrial DNA sequencing was used to investigate polecat genetic diversity in Britain. Two geographically distinct lineages were found, where one may be ancestral to the British polecat, and the other to the domestic ferret. The ancestral distribution of each lineage, or assortative mating is sufficient to explain the observed pattern. A further comparison between the distribution of the polecat phenotype and mitochondrial haplotype implies that the current population expansion may be mediated by dispersing male polecats hybridizing with female feral ferrets. However, the wild source of the ferret remains obscure. Relatively recent speciation from European mink (M. lutreola) and black-footed ferrets (M. nigripes), and/or the effects of hybridization result in an unresolved molecular phylogeny. (C) 1998 Elsevier Science Ltd. All rights reserved.
\end{abstract}

Keywords: Domestication; Hybridization; Mitochondrial DNA; Molecular ecology; Mustelidae

\section{Introduction}

Domesticated polecats or ferrets (Mustela furo) have been recorded in association with humans since the fourth century BC when Aristotle described them in a treatise on animals and physiognomy (Thomson, 1951). The Old Testament also ordained that they are one of the unclean animals (Lev. XI. 29 and 30; Thomson, $1951)$ and Strabo ( 63 BC-24 AD) reported that 'Libyan' ferrets were used to rid the Balearic Islands of a plague of rabbits (Thomson, 1951; Blandford, 1987). However, except for recent speculation regarding their origin (Zeuner, 1963; Blandford, 1987 and references therein), and some biological studies on their morphology

\footnotetext{
* Corresponding author. Angus Davison at Department of Genetics, Q.M.C., University of Nottingham, Nottingham NG7 2UH, UK. Tel.: 0115-924-9924 ext. 43100; fax: 0115-970-9906; e-mail angus.davison@nott.ac.uk
}

and karyotype (Frykman, 1972; Grafodatskii et al., 1982; Wang et al., 1984), almost no progress has been made in uncovering the centre of their domestication.

Even the parent species of domestic ferrets are uncertain. They may have been domesticated from the European polecat ( $M$. putorius), or from its eastern congener, the steppe polecat (M. eversmannii), which has a superficially more similar cranial morphology (Blandford, 1987). Since $M$. putorius and $M$. eversmannii are occasionally reported to hybridize where they overlap in their distribution, the reality of a true species split has been debated (Blandford, 1987), and several authors have at least considered whether $M$. putorius, $M$. eversmannii, and the endangered $M$. nigripes from North America (black-footed ferret) could be viewed as one Holarctic species (Anderson, 1977; Anderson et al., 1986; O’Brien et al., 1989). Black-footed ferrets and polecats produce fertile 
hybrids in captivity (D. Kwiatkowski, pers. comm.) and judging from the distribution of mummified remains, could have been sympatric in the Pleistocene (Youngman, 1994).

In Britain, domestic ferrets were probably introduced for hunting rabbits (Oryctolagus cuniculus), possibly by the Normans, or as late as the fourteenth century (Thomson, 1951). Inevitably, some domestic ferrets escaped and may have hybridized with native polecats (M. putorius) which were widespread and common at the time. Polecats began to decline around 1850, becoming extinct throughout much of England and Scotland, and reaching a nadir in the years prior to World War I. Along with a number of other British carnivores which survived in relict populations (wildcats, Felis silvestris; pine martens, Martes martes; Langley and Yalden, 1977; Strachan et al., 1996; Messenger et al., 1997), the near extinction of the polecat was a direct result of persecution by gamekeepers (Langley and Yalden, 1977).

A small population of polecats survived in a core area centred around Aberystwyth and Aberdovey, and in lower numbers in the English border counties of Herefordshire and Shropshire (Langley and Yalden, 1977; Harris et al., 1995). In the post-war era, sporting estates fell into decline so that polecats were soon reported to be increasing in numbers (Langley and Yalden, 1977). The relaxation from persecution, the banning of the gin trap in the 1950s, and the post-myxomatosis increase in rabbit numbers has apparently allowed polecats to expand their range, continuing to the present day where polecats have been recovered as far east as Oxfordshire and Northamptonshire (Birks, 1993, 1995, 1997). In addition, polecats have been covertly re-introduced to parts of Scotland (e.g. Argyll), Cumbria, and southern England.
Concern has arisen as to the extent of polecat/ domestic ferret introgression in Britain, and particularly, whether the eastern edge of the expanding population and re-introduced populations are of mainly hybrid or ferret origin. Is the genetic integrity of the polecat threatened by hybridization, as has happened with Scottish red deer (Cervus elaphus; Abernethy, 1994), the wild cat (Felis silvestris; Balharry et al., 1994) and the red wolf (Canis rufus, Brownlow, 1996)? We used mitochondrial DNA sequencing to question whether any British polecat/ferret populations remain genetically distinct despite hybridization. Additionally, the molecular phylogenetics of the genus Mustela was investigated, to place the conservation of British polecats into a wider perspective. Is it more realistic to consider M. putorius, M. eversmannii, M. nigripes, and their domestic counterpart M. furo as one Holarctic species? This is especially relevant given the controversy on the biological unit that should be conserved (Avise, 1994; Balharry et al., 1994; Brownlow, 1996; Moritz, 1994; Wayne and Gittleman, 1995).

\section{Methods}

\subsection{Sampling}

Appeals for road casualty polecats and feral ferrets were made between 1993 and 1996, coordinated by the Vincent Wildlife Trust (V.W.T.) and the National Museums of Scotland. All corpses were delivered to the National Museums of Scotland where they were skinned and their livers frozen. The road accident site grid reference was noted. Specimens from outside the UK, and other Mustela species were collected from a variety of sources (Table 1).

Table 1

Main sources of animals used in this study

\begin{tabular}{|c|c|c|c|c|}
\hline Species & Common name & Locality a & Number & Source \\
\hline \multirow[t]{4}{*}{ Mustela putorius/M. furo } & European polecat/ferret & UK & $>80$ & JDSB, ACK, C. Craik \\
\hline & & E. Slovenia & 8 & A. Gergar B. Krystufek, HIG \\
\hline & & U. Rhine Valley, Germany & 4 & R. Allgower \\
\hline & & Thrace, Turkey & 1 & B. Krystufek \\
\hline M. eversmannii & Siberian polecat & E. Inner Mongolia & 8 & DB \\
\hline \multirow[t]{2}{*}{ M. eversmannii } & Steppe polecat & N. W. Serbia & 1 & B. Krystufek \\
\hline & & Zamojskie, Poland & 1 & H. Schofield \\
\hline \multirow[t]{2}{*}{ M. erminea } & Stoat or ermine & Cambridge, UK & 1 & HIG \\
\hline & & Co. Waterford, Ireland & 1 & P. Smiddy, P. Sleeman \\
\hline M. frenata & Long tailed weasel & Colombia, S. Am. & 1 & D. Fawcett \\
\hline M. lutreola & European mink & Tver region, Russia & 1 & T. Maran \\
\hline M. nigripes & Black-footed ferret & USA & 7 & DB \\
\hline M. nivalis & Weasel & E. Slovenia & 1 & A. Gergar, B. Krystufek, HIG \\
\hline M. vison & American mink & Oxford, UK & 9 & D. Macdonald, N. Yamaguchi \\
\hline Meles meles & European badger & Cornwall, UK & 1 & V. Simpson \\
\hline
\end{tabular}

a See text and figures for further information. Full details are available on request from AD. 


\subsection{Morphological measurements}

Skull and pelage characters were scored from over 200 British animals. Pelage characters were: extent of muzzle coloration, presence/absence of cheek patches and frontal band, coloration of underfur on body, coloration of underfur on limbs and tail, coloration of paws, presence/absence of scattered white hairs over body, coloration of dorsal surface, coloration of ventral surface, coloration of limbs, coloration of tail, and length of throat patch ( $>$ or $<60 \mathrm{~mm}$ ). Skull measurements were: condylobasal length, palatal length, zygomatic breadth, interorbital breadth, ectorbital breadth, postorbital breadth, length of postorbital region, mastoid breadth, foramen magnum width, foramen magnum height, upper carnassial length, upper carnassial width, upper canine length, upper canine width, mandible length, mandibular ramus height, auditory bulla length, auditory bulla width, braincase height, and greatest length of skull. Skull characters were: shape of postorbital region, shape of hamular processes, and presence/absence of supernumerary incisors. Skull and pelage characters were scored on a scale of 1-3, where a polecat-like character scored 3 and a ferret-like one 1. Cranial volume was also measured. Following a multivariate analysis each individual was then assigned a 'polecat' or 'domestic ferret' phenotype. Anything other than a phenotypically pure polecat was regarded as a domestic ferret/ hybrid for the molecular genetic analysis in this paper. The detailed analysis of the morphological work will be published elsewhere (Kitchener et al. in prep.).

\subsection{Mitochondrial DNA sequencing}

Genomic DNA was extracted from either liver, blood, or skin and hair specimens, alongside an extraction blank, using Qiagen Blood/Tissue purification kits. Mitochondrial DNA fragments were amplified using the polymerase chain reaction (PCR), including approximately $50 \mathrm{ng}$ of template DNA in each reaction. Three separate mitochondrial fragments were amplified, all of which required the same cycling parameters of a 5 min denaturing step at $96^{\circ} \mathrm{C}$, followed by 35 cycles of $60 \mathrm{~s}$ at $94^{\circ} \mathrm{C}, 60 \mathrm{~s}$ at $55^{\circ} \mathrm{C}$, and $60 \mathrm{~s}$ at $72^{\circ} \mathrm{C}$ with $0.25 \mathrm{U}$ Thermoprime taq polymerase (Advanced Biotechnologies) and $1.5 \mathrm{mM}$ Magnesium. A cytochrome $b$ fragment was amplified using primers L14724 and H15149 (Irwin et al., 1991); latterly L14724 was replaced by L14771 (5'-CAACATTCGTAAAACCCACC-3') which produces a slightly smaller product. A 12S rRNA fragment was amplified using L1091 and H1478 (Kocher et al., 1989), and the 5' part of the control region (D-loop) amplified using L15774 and H16498 (Shields and Kocher, 1991).
Approximately $50 \mathrm{ng}$ of DNA was used to sequence in both directions, including $3.5 \mathrm{pmol}$ of the relevant primer. Two internal sequencing primers were also used with the longer control region product: L16007 (5'CCCAAAGCTAAAATTCTAA-3') and H16270 (5'CTCGTGGTCTAAGTGAGGTGGA-3').

\subsection{Phylogenetic analysis}

Phylogenetic trees were constructed from aligned DNA sequences using three methods. A minimum evolution method (neighbour-joining, Kimura 2-parameter) was performed in PHyLIP (J. Felstenstein), with a 2:1 transition: transversion ratio. Latterly, transition: transversion ratios of $1: 1$ and 10:1 were also used to test for any effect on overall tree topology, and a Tamura-Nei distance calculated in MegA (Kumar et al., 1993) to control for rate variation between sites. Maximum likelihood methods included 5 global rearrangements and were also performed in PHYLIP. PAUP v.3.1.1 (Sinauer Associates, MA) was used to identify the most parsimonious tree, using the exhaustive search option where possible; otherwise a heuristic search with the branch swapping option was performed. Trees were bootstrapped 1000 times when the method allowed. The computer program TreEview (Page, 1996) was used to help draw trees.

\section{Results}

\subsection{Mitochondrial sequence variation between polecats and domestic ferrets}

A 337 base pair (bp) fragment of the mitochondrial cytochrome $b$ gene and/or a 375 bp control region fragment (when aligned) was sequenced from 64 mainland British polecats and domestic ferrets. The size of the Dloop fragment was dependent upon variations in the length of a polypyrimidine $C_{n} T_{n}$ tract. The same regions were also sequenced for one feral ferret from Benbecula, two from Shetland (both Scotland, see Fig. 1), and one from the Isle of Man (see Fig. 1 for location). Only two cytochrome $b$ haplotypes were discovered, differing by a single base transition substitution at a third codon position. The geographic distribution of the two mitochondrial haplotypes is mapped in Fig. 1. One haplotype was confined to Wales and western central England, whereas the other was found in mainland England, Wales and Scotland, the islands (Benbecula, Shetland, Isle of Man) and re-introduced polecat/feral ferret populations (Argyll, Cumbria, and New Forest; see Fig. 1 for locations). The cytochrome $b$ sequence of the latter haplotype was identical to two domestic ferret cytochrome $b$ sequences on the GenBank database (Lento et al., 1995; Ledje and Arnason, 1996a). Also, the two cytochrome $b$ haplotypes 


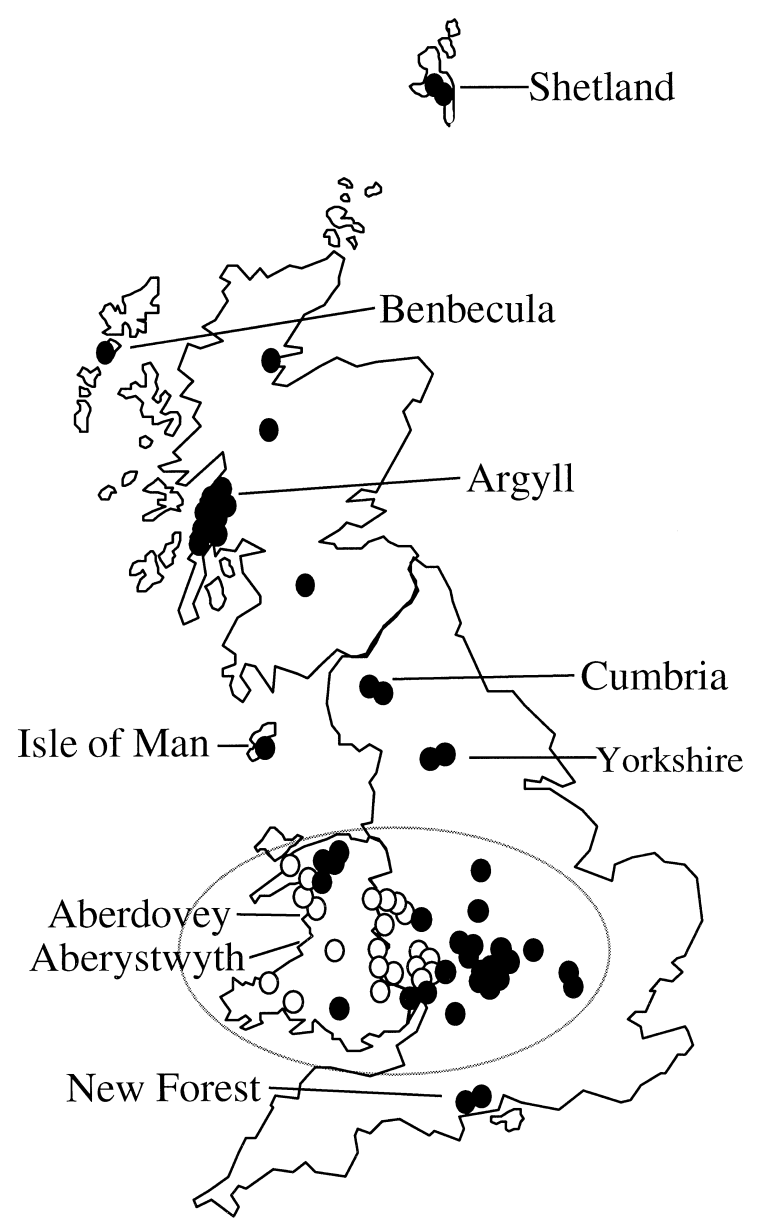

Fig. 1. Distribution of each of the two clades of polecat/domestic ferret mitochondrial haplotypes across Britain. Empty circles represent the Welsh polecat (WP) clade, filled circles the domestic ferret (F) clade. All sampled populations outside the ellipse probably arose as a result of introductions. The countryside around Aberdovey has been proposed as the polecat refugium.

corresponded to two distinct D-loop clades (see below). Therefore, the mitochondrial haplotypes are referred to as 'Welsh polecat' (WP) and 'domestic ferret' (F), reflecting their current predominant distributions in Britain. Note that the $\mathrm{F}$ haplotype was also found in a phenotypically pure Slovene polecat.

The area centred around Aberystwyth and more recently, Aberdovey (Wales, see Fig. 1 for locations; Harris et al., 1995), has been regarded as the refuge of the polecat in Britain. A comparison was made between the frequency of haplotype (WP or F) or morphology (polecat or domestic ferret) against linear distance from Aberdovey (Fig. 2). The polecat phenotype was present further East than the polecat matriline.

A minimum evolution tree (neighbour-joining method) was constructed using cytochrome $b$ sequences from this study and those of Masuda and Yoshida (1994); Fig. 3a). Trees with essentially the same topology were produced with all phylogenetic methods (minimum evolution using the neighbour-joining algorithm in con-

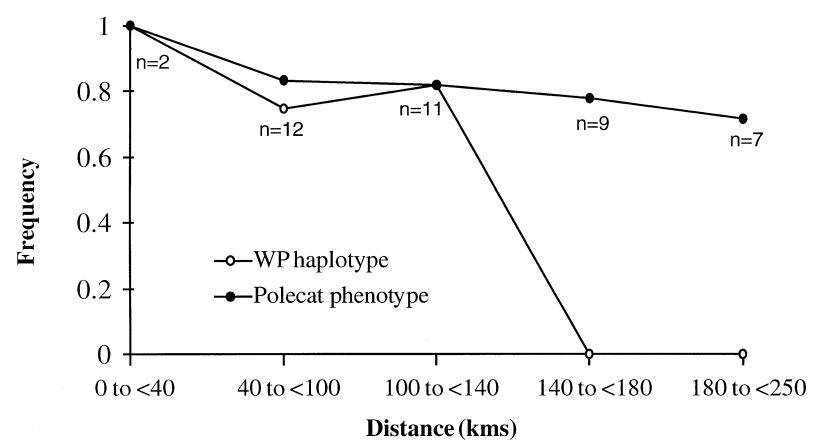

Fig. 2. Graph showing frequency of the Welsh polecat haplotype (WP) and polecat phenotype against linear distance from Aberdovey. The polecat phenotype is present further east than the WP haplotype.

junction with either the Kimura 2-parameter model and varying transition:transverion ratios or a Tamura-Nei distance, parsimony, and maximum likelihood), except that positions within the polecat/ferret clade varied, or else $M$. itatsi and $M$. sibirica were an ingroup to $M$. nigripes (in the parsimony tree). The lack of resolution between polecats and ferrets was presumably a result of insufficient sequence variation, and is reflected in a lack of bootstrap support.

Fig. 3b shows a neighbour-joining tree constructed from combined cytochrome $b$ and D-loop sequences. The variation found between D-loop haplotypes is shown in Fig. 4. Sequences from the two regions were combined, because despite potential problems in accommodating different models of evolution (Huelsenbeck et al., 1996), the greater priority was that maximum sequence variation should be utilised. In any case, a tree of similar topology tree was produced using D-loop sequence alone (tree not shown). A consensus tree using exhaustive parsimony, and maximum likelihood methods also resulted in trees of similar topology, except the D10/D13 node was not resolved, leading to a trifurcation. Variation in a hypervariable $C_{n} T_{n}$ array (see Fig. 4) was not included in the tree construction as reliable alignment of this region was not possible. Attempts to superimpose the indel events on the parsimony tree required reticulation. Similar polypyrimidine tracts have been identified in other mammals (Zardoya et al., 1995).

The two distinct groups of British polecats/ferrets in the phylogenetic tree in Fig. 3b suggest that the two cytochrome $b$ haplotypes that differ by a single base (WP and F) correspond to two good clades, particularly since individuals with a particular cytochrome $b$ haplotype all belonged to the same D-loop clade $(n=16)$. Individuals from one of these D-loop clades were not found outside Wales and the adjoining English border counties (haplotypes D10, D11 and D13). The same Slovene polecat as mentioned earlier (C6, D3 in Fig. 3) fell within the domestic ferret clade, although the sequence differed from the nearest neighbour by a two base deletion. 

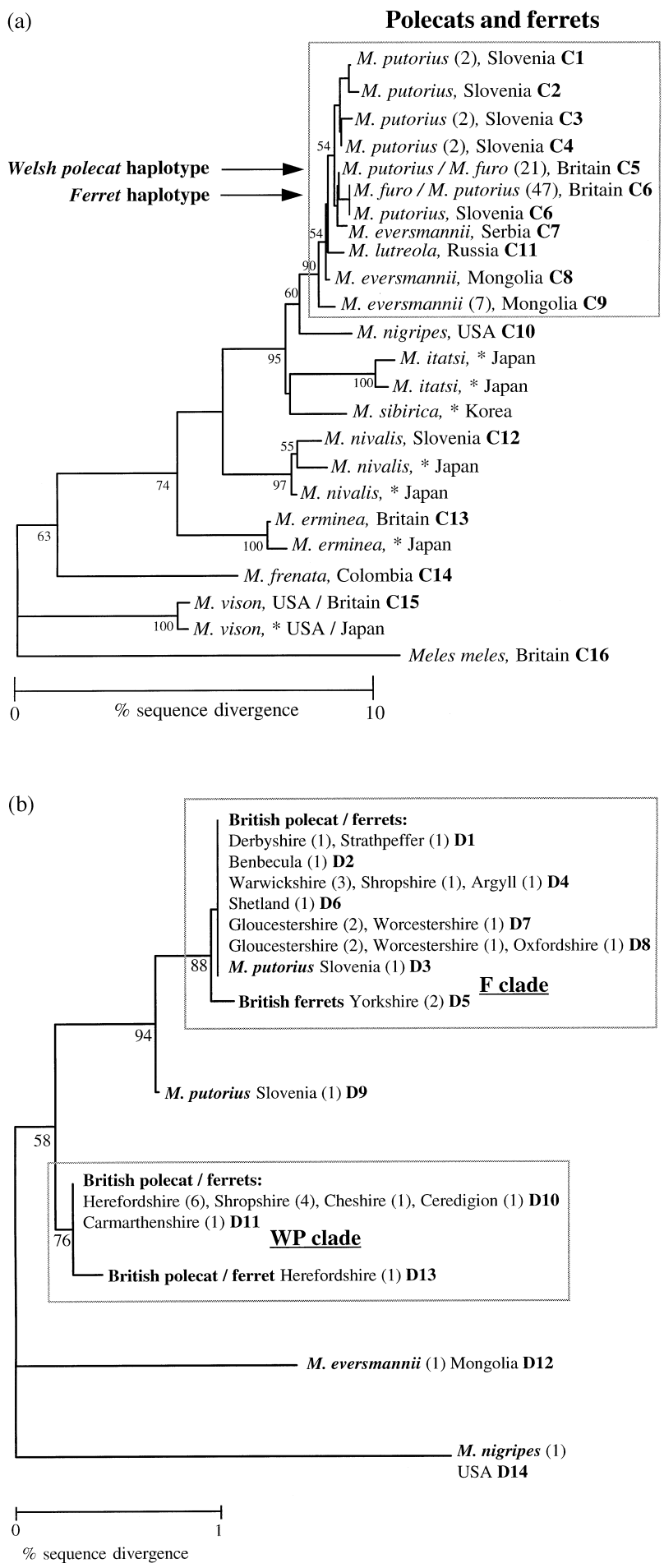

Fig. 3. Neighbour-joining trees showing relationships between members of the genus Mustela. Bootstrap values ( $>50 \%$ only) are shown below each node. The figure in brackets is the number of individuals identified with that sequence. (a) Tree from combined cytochrome $b$ sequence data from this paper, and Masuda and Yoshida (1994); indicated by a *). Cytochrome $b$ haplotypes $\mathrm{C} 1$ to $\mathrm{C} 16$ have GenBank accession numbers AF068534 to AF068549. (b) Tree constructed from combined cytochrome $b$ (337 bp) and D-loop sequence ( $\sim 375 \mathrm{bp})$. Where more than one haplotype is present on a single branch, the sequence differed only by an insertion or deletion. The haplotypes D1 to D14 have GenBank accession numbers AF068558 to AF068571.
Although it was not possible to align the $C_{n} T_{n}$ tract, all of the F clade contained a unique $T_{4}-T_{9}$ stretch (positions $157-165$ in Fig. 4), not found in the WP clade.

The 12S rRNA sequences are also consistent with a ferret clade (including also the single Slovene polecat), although recurrent mutation may be a problem as with all low sequence divergence comparisons. All polecat (M. putorius, $n=4$, M. eversmannii, $\mathrm{n}=1$ ) and European mink $(n=1)$ 12S rRNA haplotypes were the same (GenBank AF068550), except domestic ferret/Slovene polecat $(n=3,1$; GenBank AF068551), and the blackfooted ferret $(n=1$; GenBank AF068552), which differed from the polecat sequence in a single position. The domestic ferret 12S rRNA sequence agreed with that determined by Ledje and Arnason (1996b).

\section{Discussion}

\subsection{Conservation genetics of the polecat in Britain}

Two distinct mitochondrial polecat lineages exist in Britain (Fig. 1; Fig. 3b). One of them (the WP haplotype) is centred on Wales and the English border counties, whilst the other $(F)$ is found throughout Britain, and probably wherever there are feral ferrets. The current WP haplotype distribution includes the polecat refugial counties, and the F haplotype is the same as in pure-bred feral ferrets from the Scottish islands and two previously sequenced domestic ferret cytochrome $b$ fragments (Lento et al., 1995; Ledje and Arnason, 1996a). Therefore, it is likely that the haplotypes in Britain derive from the Welsh polecat and the domestic ferret, respectively. Conversely, the geographic distribution is probably not a relict of a polecat ancestral polymorphism, and though introgression between the polecat and feral ferret occurs, the mitochondrial DNA haplotypes have maintained their distributions as largely distinct to the present day. The pattern may reflect a historical distribution of polecats and domestic ferrets that has persisted even beyond the World War I bottleneck, because polecats have always been more abundant in mid-Wales, and the reverse was true elsewhere after the local extinction of the polecat.

However, wild polecats are surprisingly tolerant of human activity, and often inhabit the vicinity of settlements or rabbit burrows where they may meet domestic ferrets (JDSB unpub. data; Blandford, 1987; Weber, 1989). Since domestic ferrets have been selectively bred in captivity for hundreds of years (MacKay, 1995), the resulting qualities of docility and tameness may limit the capacity of ferrets to survive and breed in the feral state (Poole, 1972). These circumstances will favour strong selection for a polecat 'phenotype', and may explain why the enduring feral ferret colonies are found on offshore islands where native predators are scarce or absent (Blandford and Walton, 1991). 
$\begin{array}{lllllllllllllll}29 & 58 & 116 & 121 & 147 & 150 & 151 & 152 & 153 & 154 & 155 & 156 & 157 & 158 & 159\end{array}$

\begin{tabular}{|c|c|c|c|c|c|c|c|c|c|c|c|c|c|}
\hline D1 & $\mathrm{T}$ & $\mathrm{T}$ & $\mathrm{T}$ & $\mathrm{T}$ & $\mathrm{T}$ & $\mathrm{T}$ & $\mathrm{T}$ & $\mathrm{T}$ & $\mathrm{T}$ & _ & - & C & $\mathrm{T}$ \\
\hline D2 & . & • & . & . & . & . & . & . & . & - & - & . & . \\
\hline D3 & . & . & . & . & . & . & . & . & . & - & - & . & . \\
\hline D4 & . & . & . & . & . & . & . & . & . & - & - & . & • \\
\hline D5 & . & . & . & . & . & . & . & . & . & - & - & . & • \\
\hline D6 & . & . & . & . & . & . & . & . & . & - & - & . & - \\
\hline D7 & . & . & . & . & • & . & • & . & . & - & - & . & - \\
\hline D8 & . & . & . & . & . & . & . & . & . & - & - & . & • \\
\hline D9 & A & . & C & . & . & . & . & . & . & $\mathrm{T}$ & - & . & • \\
\hline D10 & A & . & C & . & . & . & . & . & . & $\mathrm{T}$ & - & . & - \\
\hline D11 & A & . & C & . & . & . & . & . & . & $\mathrm{T}$ & $\mathrm{T}$ & . & - \\
\hline D12 & A & C & C & . & C & C & C & C & C & $\mathrm{T}$ & - & . & C \\
\hline D13 & A & . & C & . & . & . & . & . & . & $\mathrm{T}$ & - & . & - \\
\hline D14 & A & . & C & C & . & . & . & - & - & - & - & . & . \\
\hline
\end{tabular}

$\begin{array}{llllllllllllll}160 & 161 & 162 & 163 & 164 & 165 & 166 & 167 & 168 & 169 & 170 & 171 & 172 & 173\end{array}$

\begin{tabular}{|c|c|c|c|c|c|c|c|c|c|c|c|c|c|c|}
\hline D1 & $\mathrm{T}$ & $\mathrm{T}$ & $\mathrm{T}$ & $\mathrm{T}$ & $\mathrm{T}$ & - & C & C & C & C & C & C & C & C \\
\hline D2 & . & . & - & - & - & - & - & . & . & . & . & . & . & . \\
\hline D3 & . & - & - & - & - & $\mathrm{C}$ & . & . & . & . & . & . & . & . \\
\hline D4 & . & . & . & . & . & - & - & . & . & . & . & . & . & . \\
\hline D5 & . & . & . & . & . & - & - & . & . & . & . & . & . & . \\
\hline D6 & . & . & . & . & . & $\mathrm{T}$ & - & - & . & . & . & . & . & . \\
\hline D7 & . & . & . & . & . & $\mathrm{T}$ & . & . & . & . & . & . & . & . \\
\hline D8 & . & . & . & . & . & $\mathrm{T}$ & - & . & . & . & . & . & . & . \\
\hline D9 & - & - & - & - & - & - & - & . & . & . & - & . & . & . \\
\hline D10 & - & - & - & - & - & - & - & . & $\mathrm{T}$ & . & . & . & . & . \\
\hline D11 & - & - & - & - & - & - & - & . & $\mathrm{T}$ & . & . & . & . & . \\
\hline D12 & - & - & - & - & 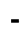 & - & - & . & $\mathrm{T}$ & . & . & . & $\mathrm{T}$ & - \\
\hline D13 & - & - & - & - & - & - & - & . & $\mathrm{T}$ & . & . & . & . & . \\
\hline D14 & . & . & . & . & . & $\mathrm{T}$ & - & . & . & . & . & . & . & \\
\hline
\end{tabular}

$\begin{array}{llllllllllllll}174 & 221 & 224 & 229 & 250 & 255 & 260 & 264 & 266 & 297 & 312 & 351 & 356 & 368\end{array}$

\begin{tabular}{|c|c|c|c|c|c|c|c|c|c|c|c|c|c|}
\hline D1 & A & A & $\mathrm{T}$ & A & C & $\mathrm{T}$ & C & G & G & C & A & 1 & C \\
\hline D2 & . & - & - & - & . & . & . & . & . & . & . & . & . \\
\hline D3 & . & . & . & . & . & . & . & . & . & . & . & & . \\
\hline D4 & . & . & . & . & . & . & . & . & . & . & . & & . \\
\hline D5 & . & . & . & . & . & . & . & . & • & $\mathrm{T}$ & . & & . \\
\hline D6 & . & . & . & . & . & . & . & . & . & . & . & 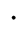 & . \\
\hline D7 & . & . & . & . & - & . & . & . & . & . & . & 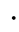 & . \\
\hline D8 & . & . & . & . & . & . & . & . & . & . & . & - & . \\
\hline D9 & . & . & . & . & . & . & . & . & . & . & . & . & . \\
\hline D10 & . & . & . & G & . & . & • & . & . & . & - & C & - \\
\hline D11 & . & . & . & G & $\dot{0}$ & $\dot{\sigma}$ & . & . & • & . & . & C & $\dot{T}$ \\
\hline D12 & - & . & . & $\mathrm{G}$ & $\mathrm{T}$ & C & . & • & . & . & . & C & $\mathrm{T}$ \\
\hline D13 & . & $\mathrm{G}$ & . & $\mathrm{G}$ & . & . & . & . & . & . & . & C & . \\
\hline D14 & . & & C & $\mathrm{G}$ & • & & $\mathrm{T}$ & A & A & $\mathrm{T}$ & G & & \\
\hline
\end{tabular}

Fig. 4. Alignment of the 14 unique D-loop haplotypes, including the variable sequence positions and all bases of the $C_{n} T_{n}$ repeat region (bases 150-174). A dot indicates identity with the first sequence and a hyphen, a deletion.

Reports commissioned by the V.W.T. on polecat densities per $10 \times 10 \mathrm{~km}$ square suggest that their population in Britain has expanded from a core refugial area in Wales and the English borders (Birks, 1993, 1995, 1997). The eastward penetration of the polecat phenotype in Fig. 2 is consistent with the population expansion being mediated by dispersing male polecats occasionally meeting pockets of feral ferrets, and/or selection favouring a polecat phenotype. Also, hybrid stock may have been introduced to Argyll, Cumbria and the New Forest, since only the $\mathrm{F}$ haplotype was discovered in these locations. However, multilocus microsatellite DNA fingerprinting will be required to fully resolve the extent of hybridization and degree of distinctness that remains between the British polecat and the ferret.

The genetic and morphometric analyses reveal that domestic ferrets in Britain hybridize with polecats, and that introgression may be extensive. As Balharry et al. (1994) point out, the deliberate backcrossing of domestic ferrets to wild polecats has occurred over many years, so that feral and domestic populations of ferrets may be genetically more similar to polecats in their own geographic region than to other ferrets. Our study suggests that in Britain two parental populations may be present which have hybridized to varying degrees depending upon the local release and survival of feral ferrets. Microsatellite work is required to show whether there is any predominant direction to the introgression. Balharry et al. (1994) suggest that polecats and even polecat/domestic ferret hybrids (as $M$. putorius rather than M. furo or M. eversmannii) may receive some protection under Schedule 6 of the British Wildlife and Countryside Act (HMSO, 1981). Unfortunately, whilst this may be true mitochondrial DNA is not sufficiently discriminatory to establish whether an individual animal is a ferret, hybrid or polecat. Again, further studies with microsatellites are required. Although the circumstances of hybridization are different, Scottish wildcats (Felis silvestris) and feral cat/wildcat hybrids are currently unprotected under Scottish law.

On a more practical level the close relationship between domestic ferrets and polecats and the probable selective advantage of the native polecat phenotype, should remove some of the problems that have beset other hybridizations of conservation concern (e.g. in stifftail ducks, Oxyura sp., Balharry et al., 1994; and cervine deer, Cervus sp., Abernethy, 1994). The spread of the native British polecat is more likely to be limited by other factors such as suitability of habitat, persecution pressure, pesticide poisoning and road traffic density.

\subsection{A holarctic species complex?}

Is it possible to resolve the major relationships within the polecat group (Youngman, 1982)? Perhaps unexpectedly, interspecific variation was generally too low to properly resolve species level relationships. In general, even bootstrap support for the major branches on the Mustela tree was poor (Fig. 3a). Variation was greatest between $M$. nigripes and $\{M$. putorius, $M$. furo, $M$. eversmannii $\}$, at just over $1 \%$ of positions in the cytochrome $b$ gene (Fig. 3a). The mitochondrial results suggest that either polecats and European mink have recently speciated, or else gene flow through hybridization has prevented haplotype divergence, resulting in an unresolved molecular phylogeny. Therefore, the molecular genetics does not resolve whether ferrets were originally domesticated from $M$. putorius or $M$. eversmannii. In Britain, some local populations of polecats may now be most closely related to feral ferrets through hybridization. Furthermore, the degree of nuclear introgression of domestic ferrets and polecats may be so extensive as to rule out ever tracing their wild ancestor. 


\section{Acknowledgements}

We are grateful to the Vincent Wildlife Trust for providing a one year research assistantship to $\mathrm{AD}$, and indebted to numerous persons who collected specimens, particularly Boris Krystufek, Clive Craik and Paddy Sleeman (see Table 1 for details of the other main collectors). Ruth Pollett, Vivienne Pratt, Jacqui Kay, Catriona MacLeod and John Mackenzie helped process the corpses. Black-footed ferret tissue specimens were either loaned from the Natural History Museum, or imported to Britain under special permit, number 84675 . We are also grateful to two referees for helpful comments.

\section{References}

Abernethy, K., 1994. The establishment of a hybrid zone between red and sika deer (genus Cervus). Molecular Ecology 3, 551-562.

Anderson, E., 1977. Pleistocene Mustelidae (Mammalia, Carnivora) from Fairbanks, Alaska. Bulletin of the Museum of Comparative Zoology 148, 1-21.

Anderson, E., Forrest, S.C., Clark, T.W., Richardson, L., 1986. Paleobiology, biogeography, and systematics of the black-footed ferret, Mustela nigripes (Audubon and Bachman, 1851). Great Basin Naturalist Memoirs 8, 11-62.

Avise, J.C., 1994. Molecular Markers, Natural History and Evolution. Chapman and Hall, New York.

Balharry, E., Staines, B.W., Marquiss, M., Kruuk, H., 1994. Hybridisation in British Mammals. JNCC Report No. 154. Joint Nature Conservation Committee, Peterborough, UK.

Birks, J.D.S., 1993. The return of the polecat. British Wildlife 5, 16-25.

Birks, J.D.S., 1995. Recovery of the European polecat (Mustela putorius) in Britain. Small Carnivore Conservation 12, 9.

Birks, J.D.S., 1997. A volunteer-based system for sampling variations in the abundance of polecat (Mustela putorius). Journal of Zoology (London) 243 (4), 857-863.

Blandford, P.R.S., 1987. Biology of the polecat Mustela putorius: a literature review. Mammal Review 17 (4), 155-198.

Blandford, P.R., Walton, K.C., 1991. Feral ferret Mustela furo. In: (Eds.), Corbett, G.B., Harris, S. The Handbook of British Mammals. Blackwell Scientific Publications, Oxford, pp. 405-406.

Brownlow, C.A., 1996. Molecular taxonomy and the conservation of the red wolf and other endangered carnivores. Conservation Biology 10 (2), 390-396.

Frykman, I., 1972. Chromosome studies of Mustela putorius in tissue culture. Hereditas 70, 59-68.

Grafodatskii, A., Ternovskaya, Y., Ternovskii, D., 1982. Distribution of structural heterochromatin and the nucleolar organizer regions in the chromosomes of Siberian polecat, mink, and their hybrids. Doklady Akademii Nauk SSSR 262, 34-36.

Harris, S., Morris, P., Wray, S., Yalden, D., 1995. A Review of British Mammals: Population Estimates and Conservation Status of British Mammals Other than Cetaceans. Joint Nature Conservation Committee, Peterborough.

HMSO, 1981. Wildlife and Countryside Act. Her Majesty's Stationery Office, London.

Huelsenbeck, J.P., Bull, J.J., Cunningham, C.W., 1996. Combining data in phylogenetic analysis. Trends in Ecology and Evolution 11 (4), 152-158.

Irwin, D.M., Kocher, T.D., Wilson, A.C., 1991. Evolution of the cytochrome $b$ gene of mammals. Journal of Molecular Evolution 32, 128-144.
Kocher, T.D., Thomas, W.K., Meyer, A., Edwards, S.V., Pääbo, S., Villablanca, F.X., Wilson, A.C., 1989. Dynamics of mitochondrial DNA evolution in animals: amplification and sequencing with conserved primers. Proceedings of the National Academy of Sciences USA Vol. 86, pp. 6196-6200.

Kumar, S., Tamura, K., Nei, M., 1993. MEGA: Molecular Evolutionary Genetics Analysis, version 1.01. Pennsylvania State University, University Park, PA 16802.

Langley, P.J.W., Yalden, D.W., 1977. The decline of the rarer carnivores in Great Britain during the Nineteenth Century. Mammal Review 7, 95-116.

Ledje, C., Arnason, U., 1996. Phylogenetic analyses of complete cytochrome $b$ genes of the order Carnivora with particular emphasis on the Caniformia. Journal of Molecular Evolution 42, 135-144.

Ledje, C., Arnason, U., 1996. Phylogenetic relationships within caniform carnivores based on analyses of the mitochondrial $12 \mathrm{~S}$ rRNA gene. Journal of Molecular Evolution 43, 641-649.

Lento, G.M., Hickson, R.E., Chambers, G.K., Penny, D., 1995. Use of spectral analysis to test hypotheses on the origin of pinnipeds. Molecular Biology and Evolution 12 (1), 28-52.

MacKay, J., 1995. Complete Guide to Ferrets. Swan Hill Press, Shrewsbury.

Masuda, R., Yoshida, M.C., 1994. A molecular phylogeny of the family Mustelidae (Mammalia, Carnivora), based on comparison of mitochondrial cytochrome $b$ nucleotide sequences. Zoological Science 11, 605-612.

Messenger, J., Birks, J., Jefferies, D., 1997. What is the status of the pine marten in England and Wales? British Wildlife 8 (5), 273-279.

Moritz, C., 1994. Defining 'evolutionary significant units' for conservation. Trends in Ecology and Evolution 9 (10), 373-375.

O'Brien, S.J., Martenson, J.S., Eichelberger, M.A., Thorne, E.T., and Wright, F., 1989. Genetic variation and molecular systematics of the black-footed ferret. In: (Eds.) Seal, U.S., Thorne, E.T., Bogan, M.A., Anderson, S.H. Conservation biology and the black-footed ferret. Yale University Press, New Haven, Connecticut, pp. 21-33.

Page, R.D.M., 1996. Treeview: An application to display phylogenetic trees on personal computers. Computer Applications in the Biosciences 12, 357-358.

Poole, T.B., 1972. Some behavioural differences between the European polecat, Mustela putorius, the ferret, M. furo, and their hybrids. Journal of Zoology (London) 166 (1), 25-35.

Shields, G.F., Kocher, T.D., 1991. Phylogenetic relationships of North American ursids based on analysis of mitochondrial DNA. Evolution 45 (1), 218-221.

Strachan, R., Jefferies, D.J., Chanin, P.R.F., 1996. Pine Marten Survey of England and Wales 1987-1988. Joint Nature Conservation Committee, Peterborough.

Thomson, A.P.D., 1951. A History of the ferret. Journal of the History of Medicine 6 (4), 471-480.

Wang, Z., Quan, G., Yie, Z., Wang, S., 1984. Karyotypes of three species of Carnivora. Acta Zoologica Sinica 30 (2), 188-194.

Wayne, R.K., Gittleman, J.L., 1995. The problematic red wolf. Scientific American July, 26-31.

Weber, D., 1989. The ecological significance of resting sites and the seasonal habitat change in polecats (Mustela putorius). Journal of Zoology (London) 217, 629-638.

Youngman, P.M., 1982. Distribution and systematics of the European Mink Mustela lutreola Linnaeus 1761. Acta Zoologica Fennica 166, $1-48$.

Youngman, P.M., 1994. Beringian ferrets-mummies, biogeography, and systematics. Journal of Mammalogy 75 (2), 454-461.

Zardoya, R., Villalta, M., Lopez-Perez, M.J., Garrido-Pertierra, A., Montoya, J., Bautista, J.M., 1995. Nucleotide sequence of the sheep mitochondrial DNA D-loop and its flanking tRNA genes. Current Genetics 28, 94-96.

Zeuner, F.E., 1963. A History of Domesticated Animals. Hutchinson, London. 